Onomastica Slavogermanica

XXXI

Wrocław 2019

DOI: 10.19195/0474-1471.31.1

Malgorzata JaRACZ

Bydgoszcz-Bettlach

\title{
Kulturowo-językowe wyróżniki niemieckojęzycznego systemu nazewniczego w Szwajcarii. Współczesna plateonimia Solothurn i Bettlach
}

Słowa kluczowe: plateonimia, tożsamość kulturowa, system plateonimów Solothurn i Bettlach

\section{Wprowadzenie}

Szwajcarska problematyka nazewnicza nie była dotąd przedmiotem zainteresowania polskich badaczy ${ }^{1}$. Warto zatem pokusić się o wycinkową analizę części współczesnego systemu plateonimicznego w ważnym historycznie dla Polaków kantonie Solothurn ${ }^{2}$, by ukazać właściwości i specyfikę tak zwanych Strassennamen lub Verkehrsnamen, a także utrwalone w nich uniwersalne europejskie zasady tworzenia nazw ulic i placów ${ }^{3}$.

${ }^{1}$ Rodzima onomastyka szwajcarska stoi na bardzo wysokim poziomie, czego dowodzą zaawansowane badania, regionalne projekty i liczne opracowania powstałe na uniwersytecie w Bernie i w poszczególnych kantonach. Zob. Das Portal der schweizerischen Ortsnamenforschung, http://ortsnamen.ch/ (dostęp: 26.07.2014).

${ }^{2}$ Kanton Solothurn ma dla Polaków wielkie znaczenie, ponieważ tu znajduje się pomnik i muzeum generała Tadeusza Kościuszki, to jest Kosciuszko Hus oraz Towarzystwo Kościuszkowskie przy Gurzelngasse 12. Zob. http://www.kosciuszkomuseum.ch/ (dostęp: 28.07.2014). W kantonie Berno, niedaleko miasteczka Büren an der Aare, zaś można oglądać pomnik i pozostałości po obozie internowania polskich żołnierzy z roku 1940. Zob. też http://de.wikipedia.org/wiki/Geschichte des Kantons Solothurn (dostęp: 3.08.2014).

${ }^{3} \mathrm{~W}$ klasyfikacji typów nazewniczych (Ortsnamen) Szwajcarzy wyróżniają następujące typy nazw (Namentypen): Flurnamen, Bergnamen, Gewassernamen, Bauwerksnamen, Burgna- 
Szwajcaria lub Konfederacja Szwajcarska (łac. Confoederatio Helvetica) jest państwem o ustroju federacyjnym i ponadsiedmiowiekowej tradycji ${ }^{4}$. Na tle innych krajów Europy Środkowej charakteryzuje się różnorodnością lingwistyczną kantonów w zakresie języka urzędowego ${ }^{5}$, ze znaczącą przewagą regionów niemieckojęzycznych, gdzie spotykamy się z osobliwymi odmianami (Mundart) dialektu alemańskiego (Schwyzerdütsch ${ }^{6}$ ). Wspomniany w tytule kanton Solothurn ${ }^{7}$ zajmuje powierzchnię $791 \mathrm{~km}^{2}$, podzieloną na 109 gmin liczących ogółem około 260 tysięcy mieszkańców. Najważniejszymi jego miastami są Solothurn ${ }^{8}$, Grenchen ${ }^{9}$, Olten i Breitenbach. W analizie onomastycznej uwzględniam stolicę kantonu ${ }^{10} \mathrm{i}$ dla porównania pradawną wieś Bettlach ${ }^{11}$ oddaloną od niej około $12 \mathrm{~km}$, a graniczącą bezpośrednio z miastem Grenchen w kierunku zachodnim.

\section{Interferencje językowe jako dziedzictwo przeszłości}

Badacze zgodnie podkreślają, że tereny te podlegały wpływom celtyckim i rzymskim, co znalazło też odzwierciedlenie w funkcjonującym tam zasobie leksykalnym i nazewniczym ${ }^{12}$. Przykładowo nazwa miasta Grenchen, z którym graniczy gmina Bettlach, została po raz pierwszy odnotowana w 1131 roku: „Der

men i Verkehrsnamen. Zob. http://ortsnamen.ch/index.php/2013-05-16-09-32-11/namentypen.html (dostęp: 26.07.2014).

4 „W 1291 kanton Schwyz (od którego wywodzi się nazwa państwa), Uri i Unterwalden sygnowały akt utworzenia zwiazku wieczystego" — http://pl.wikipedia.org/wiki/Szwajcaria (dostęp: 26.07.2014).

${ }^{5}$ W Szwajcarii są cztery języki urzędowe: niemiecki, francuski, włoski oraz romansz (retoromański). Nauczanie w szkołach podstawowych, gimnazjach i liceach odbywa się w jednym z tych języków. Zob. http://pl.wikipedia.org/wiki/Szwajcaria (dostęp: 26.07.2014).

${ }^{6} \mathrm{Na}$ temat specyfiki tego języka zob. http://de.wikipedia.org/wiki/Schweizerdeutsch (dostęp: 31.07.2014).

${ }^{7}$ Zob. oficjalna strona kantonu Solothurn: http://www.so.ch/startseite/allgemeine-informationen/portrait-kanton-solothurn.html (dostęp: 26.07.2014).

${ }^{8}$ Solothurn (Solura) leży nad rzeką Arą, jest stolicą kantonu i najpiękniejszym miastem barokowym w Szwajcarii. Obejmuje powierzchnię 629 ha z około 16,5 tys. mieszkańców. Zob. http://www.stadt-solothurn.ch/de/ (dostęp: 26.07.2014).

${ }^{9}$ Grenchen jest stolicą drugiej co do wielkości gminy w kantonie Solothurn, liczy 16726 mieszkańców (stan na koniec 2013 roku). Tu w pobliżu dworca kolejowego Bahnhof Nord znajduje się pomnik gen. Mariana Langiewicza, który był obywatelem tego miasta. Zob. http://www.grenchen.ch/de/ (dostęp: 26.07.2014).

${ }^{10} \mathrm{~W}$ opisie oznaczam je skrótami: Solothurn (S), Bettlach (B).

11 Pierwsza wzmianka źródłowa pochodzi z 1189 roku: „Von diesen wertvollen Dokumenten stammt die älteste Urkunde aus dem Jahr 1181, in welcher der Name Betelacho erstmals erwähnt wird.“ [Leimer 1981: 10]. Informacje o Bettlach http://www.bettlach.ch/ (dostęp: 26.07.2014).

${ }^{12}$ Wpływy celtyckie na tych terenach były odnotowane już w V wieku p.n.e.: „Die erste Kunde von unseren Vorfahren stammt aus dem fünften vorchristlichen Jahrhundert. In dieser Zeit drangen die Kelten in unser Land ein.“ [Leimer 1981: 15]. 
Name Grenchen ist keltisch-römisch und bedeutet so viel wie »Kornhofen«. Aus dem romanischen Granica ist das urkundliche Granechum, Grenechon, heute Grenchen geworden"13. Nazwa starszej od Grenchen osady Bettlach ma prawdopodobne korzenie łacińskie ${ }^{14}$ i wywodzona jest ze znanego typu dzierżawczego toponimów z sufiksem -acum od nazwy osobowej Paetilius jako Landgut ${ }^{15}$ des Paetelius ('dobra, włości Paeteliusa'):

Im ersten Glied steck der lateinische Personenname Paetilius, im zweiten Teil des Namens das keltisch-lateinische Suffix -acum, das eine Zugehörigkeit ausdrückt. Die Zusammensetzung lautet also Paetiliacum, d.h. Landgut des Paetilius. Paetiliacum hat sich im Laufe der Zeit lautgesetzlich zum heutigen Bettlach (Bettle) entwickelt. Wesentlich für unsere Zusammenhänge ist, dass die benachbarten Dörfer ebenfalls in diese -acum Namenlandschaft gehören: Bellach Belliacum und Selzach Selsiacum.

Ten typ toponimiczny potwierdzają nazwy sąsiednich osad jak Bellach czy Selzach (położonych jeszcze bliżej Solothurn) ${ }^{16}$.

Po bytności Celtów pozostały też inne nazwy, na przykład nazwa rzeki Aare, która przepływa przez kanton, znany oronim Wan Fluh (obecnie Wand Fluh) nazwa szerokiej ściany skalnej południowego pasma Jury górującego nad Bettlach czy inne pospolite określenia, które zachowały się w tutejszym dialekcie ${ }^{17}$.

Prawdopodobnie również nazwa miasta Solothurn ma korzenie celtycko-rzymskie. Odnotowano ją po raz pierwszy w roku 219 n.e. jako vicus Salodurum. Określenia vicus używano dla osady założonej przez Rzymian lub jej części (Stadtviertel — 'dzielnica, kwartał') ${ }^{18}$. Jednak nazwa osady Salodurum zawiera przedceltyckie słowo sal 'Wasser, wogend' i rdzeń celtycki Grundwort duron 'Tür, Tor', co daje się tłumaczyć jako 'Wassertor' (czyli ‘brama wodna'). Położenie osady nad rzeką Aare i późniejsze jej zasiedlenie przez Rzymian uzasadniają tę teorię ${ }^{19}$.

13 Zob. [Strub 1949: 2].

${ }^{14}$ Inne koncepcje odsyłają też do źródłosłowu celtyckiego Betullakon, co wydaje się mniej prawdopodobne: „Während Jahrzeiten glaubte man nach J.U. Hubschmid, der Name Bettlach stamme von keltischen Betullakon, was Birkenhain heisst. Weitere urkundliche Formen sind Bethelagia und Bethelayca.“ Badacze zwracają uwagę też na wpływy burgundzkie: „Was für alle ehemaligen burgundischen Siedlungen existierte auch für unsern Ortsnamen eine französische Form. Doch ist sie, im Gegensatz zu Grenchen (Granges) und Selzach (Sagie), nicht schriftlich erhalten. Aufgrund des Namens Batchi (im alten Dialekt von Plange und Romont BE) können wir die moderne französische Form Bâches annehmen." [Leimer 1981: 15].

15 Zob. hasło Landgut, http://de.wikipedia.org/wiki/Landgut (dostęp: 27.07.2014).

${ }^{16}$ Badania nad nazwami prowadził prof. dr Peter Glatthard na Uniwersytecie w Bernie [Leimer 1981: 10].

${ }^{17} \mathrm{~W}$ opisie historii Betlach wymienione są wyraziste przykłady: „Einige Wörter keltischer Herkunft seien hier aufgeführt: Aare Adlerweib, Balm überhängender Fels, Lebern Berg, Wan Fluh.“ W dialekcie Solothurn mamy takie poświadczenia jak na przykład: „Die solothurnische Mundart enthält auch aus dem Keltischen stammende Gattungsnamen für ganz bestimmte Dinge wie z.B. Chriss abgefallene Tannadeln, Gufe Stecknadel, Chrinne Spalt.“ [Leimer 1981: 15].

${ }_{18}$ Zob. http://de.wikipedia.org/wiki/Vicus (dostęp: 26.07.2014).

19 Zob. objaśnienie nazwy http://de.wikipedia.org/wiki/Solothurn (dostęp: 27.07.2014). 
Jak wynika z zaprezentowanych rozważań, ważnym momentem rozwoju językowego i ekonomiczno-kulturowego kantonu Solothurn było przybycie Rzymian ${ }^{20}$, którzy zorganizowali podstawową sieć dróg na tym terenie, by utrzymywać stałą łączność z odległymi garnizonami. Tę rzymską metodę budowy szlaków komunikacyjnych wykorzystano również znacznie później, w XVIII wieku. Przykładowo w gminach Bettlach i Grenchen są precyzyjnie opisane dwie antyczne drogi; jedna o nazwie Flurstrasse w kierunku Solothurn przez osadę Selzach (Chappelistrasse) i dalej na wschód ${ }^{21}$. Druga ciągnie się przez Grenchen (na południe znana jako Därte, czyli Hochstrasse), wieś Bettlach, osadę Altreu aż do Solothurn ${ }^{22}$.

Historycy odnotowali też ślady obecności plemion germańskich, na przykład Alemanów (Alamannen lub Alemannen), którzy przywędrowali tu około roku 260 n.e. i pozostali do około 450 roku n.e. ${ }^{23}$ Po nich pozostały liczne anojkonimy (Flurnamen ${ }^{24}$ ) w Bettlach, na przykład Neu Zelg, Rüttimatt, Burgzelgli, Altrüttiberg, Bruechfeld ${ }^{25}$. Do dzisiaj mówi się też o krainie geograficzno-historycznej o nazwie Alemania (niem. Alamannia, Alemannia), obejmującej między innymi znaczny obszar Szwajcarii niemieckojęzycznej z centralnym miastem Zurychem ${ }^{26}$. Drugim plemieniem germańskim, które przybyło z zachodu, byli Burgundowie (Burgunder) zajmujący Solothurn oraz okręg (tak zwany Bezirk) Lebern z miastem Grenchen ${ }^{27}$.

Innym ważnym epizodem z zamierzchłej historii tych terenów jest czas panowania frankońskich Karolingów i Merowingów, którzy objęli we władanie (tak zwany Grafschaft) tereny kantonu Freiburg, ale też obszary na lewym brzegu rzeki Aare, należące do kantonów Solothurn i Bern ${ }^{28}$.

${ }^{20} \mathrm{~W}$ międzyczasie gościli tu krótko też Helweci, którzy przywędrowali z południa około 100 roku n.e., ale po niespełna pół wieku wycofali się z tych terenów, paląc swe osady [Leimer 1981: 15].

21 „Das eine führte nördlich der Landstrasse über Bettlach, Selzach nach Solothurn und weiter ostwärts. Ihr Ausgangspunkt lag im Waadtland, wo eine römische Strasse aus Frankreich sich mit jener über den Grossen St. Bernhard vereinigte.“ [Leimer 1981: 16].

22 „Der andere Römerweg zog durch die Witi unterhalb des Fussballplatzes über das sogennante Römerbrüggli. Er kam von Meinisberg und führte über Grenchen, Bettlach und Altreu nach Solothurn. Auf Bettlacher Boden ist im Laufe der Jahre eine grosse Strecke davon in der Aare versunken. Südlich von Grenchen hiess das entsprechende Wegteilstück Därte, was soviel wie Hochstrasse bedeutet." [Leimer 1981: 16].

${ }^{23}$ Zob. „Einfall der Alamannen und Burgunder“ [Leimer 1981: 21].

${ }^{24}$ Flurnamen (Flur — 'niwa, łan') są odpowiednikami w terminologii toponomastycznej anojkonimów, czyli terenów niezamieszkanych. Zob. http://de.wikipedia.org/wiki/Flurname (dostęp: 30.07.2014).

25 „So enthnehmen wir einen alten Dorfplan aus dem Jahre 1822 nach folgende Flurnamen: Neu Zelg, Rüttimatt, Burgzelgli, Altrüttiberg, Bruechfeld." [Leimer 1981: 23-24].

${ }^{26}$ Zob. http://pl.wikipedia.org/wiki/Alemania (dostęp: 26.07.2014).

27 Zob. Die Völkerwanderungszeit (406-888) [Strub 1949: 15].

${ }^{28}$ Zob. [Leimer 1981: 21]. 
Świadectwem bytności różnych plemion w tym regionie Szwajcarii i wynikających z tego interferencji kulturowo-językowych są również nazwy ulic. Spotykamy zatem plateonimy zawierające pamiątkowe etnonimy: Burgunderstrasse (S), Keltenstrasse (S), Römerstrasse (S), Alamannenweg (B), Burgunderweg (B), Frankenweg (B), Römerweg (B).

\section{Struktura nazewnicza plateonimów i ich ortografia}

System plateonimiczny w niemieckojęzycznej części Szwajcarii charakteryzuje się obecnością złożonych nazw miejskich, co nie jest osobliwością, gdyż takie formy są powszechne w całym obszarze germańskim. Strukturę tych nazw przedstawia się schematycznie jako połączenie członu odróżniającego B (w prepozycji) z członem utożsamiającym A, co jest odwrotnym szykiem niż w polskiej $^{29}$ urbanonimii czy plateonimii.

Przykładowo:

ul. Bydgoska $<$ ulica + przymiotnik od nazwy Bydgoszcz z sufiksem -ski zestawienie dwuczłonowe $<$ człon utożsamiający A + człon odróżniający B ale:

Baslerstrasse $<$ Basel + Strasse

nazwa złożona < nazwa miejscowości Basel z interfiksem -er + człon Strasse 'ulica'

nazwa złożona < człon odróżniający B + człon utożsamiający A

Wśród nazw niemieckich zwraca też uwagę użycie różnie kwalifikowanych co do ważności i wielkości ciągów komunikacyjnych określeń typu: 1. Strasse (ulica), na przykład Grenchenstrasse (S), 2. Gasse ('uliczka, zaułek'), na przykład Adlergasse (S), Storchengasse (S), z możliwością użycia członu zdrobniałego z typowo szwajcarskim sufiksem -li , na przykład Rebgässli obok nazwy Rebgasse (S), Hofergässli (B) lub 3. Weg ('droga, ścieżka, trasa'), na przykład Eschenweg (S) i ze zdrobnieniami, na przykład Wachtwegli (B).

Interesująco przedstawia się też sprawa ortografii tych nazw, to jest plateonimy z mianami osobowymi zapisuje się z użyciem łącznika, najczęściej przed członem utożsamiającym, na przykład Edmund Wyss-Strasse (S), Hana HuberStrasse (S), Josef Reinhart-Weg (S), Jost Greder-Weg (S), Niklaus Konrad-Strasse (S), Stephan Jaeggi-Strasse (S).

${ }^{29}$ Taki szyk jest charakterystyczny dla polszczyzny. W innych językach słowiańskich mamy relację prepozycyjną, na przykład czeskie Pražská ulice, Vitězné náměstí, słoweńskie Ventúrska ulica, Hviezdoslavovo námestie, choć w przypadku nazw patronalnych niederywowanych pozostaje szyk postpozycyjny, na przykład czeskie ulice Boženy Němcové, náměstí Jana Palacha, słoweńskie Ulica vysokoškolákov, Námestie hrdinov (przykłady podane przez M. Harvalika). 
Ze względu na położenie ulicy nazwy przyjmują formę dwuczłonowych zestawień z następującymi określeniami przymiotnikowymi: 1. Obere (oberer - 'górny'), na przykład Obere Greibengasse (S), Obere Steingrubenstrasse (S), Oberer Winkel (S), 2. Mittlere (mittlerer — 'średni'), na przykład Mittlere Greibengasse (S), 3. Untere (unterer - 'dolny'), na przykład Untere Greibengasse (S), Untere Steingrubenstrasse (S), Untere Sternengasse (S), Unterer Winkel (S), Untere Einschlagstrasse (B). Niekiedy plateonimy tworzą bliźniacze pary, na przykład Obere Steingrubenstrasse - Untere Steingrubenstrasse, Oberer Winkel-Unterer Winkel.

Czasem nazwy ulic sygnowane są dodatkowymi określeniami czasowymi, na przykład Alte (alt - 'dawny, stary'): Alte Bernstrasse (S) lub Neue (neu 'nowy'): Neue Zelgstrasse (B).

Spotykamy też struktury z przyimkiem typu von, często z jego formą ściągniętą vom, na przykład Vom Staal-Weg (S), Von Roll-Weg (S), Von Sury-Weg (S), Von Wigier-Weg (S), ale nie mają one charakteru topograficznego, ponieważ von jest składową częścią nazwiska patronalnego ${ }^{30}$.

Zwraca też uwagę wykorzystanie tego samego członu odróżniającego w złożeniach z innymi członami utożsamiającymi, na przykład Wengibrücke, Wengisteinstrasse, Wengistrasse (S) lub Rathausgasse, Rathausplatz (S).

Poza typowymi strukturami w badanym materiale odnotowujemy nieliczne złożenia z elementem utożsamiającym typu Allee, Platz, Brücke, na przykład $\mathrm{Fe}$ getzallee (S), Amthausplatz (S), Kreuzackerbrücke (S), Wengibrücke (S).

Ciekawe z punktu widzenia interferencji językowych oraz uzasadnione historycznie i topograficznie są również pojawiające się w plateonimii położonego nad rzeką Aare miasta Solothurn formy nazw z postpozycyjnym członem -quai (pochodzącym z języka francuskiego w znaczeniu 'nadbrzeże, bulwar'), na przykład Landhausquai (S), Kreuzackerquai (S) ${ }^{31}$.

Alemańskie pochodzenie ma osobliwy człon -rain ${ }^{32}$, który występuje w wielu nazwach miejscowości w Niemczech, Szwajcarii oraz wśród analizowanych nazw miejskich i wiejskich, na przykład Blumenrein (S), Sonnenrein (B), Zelglirein (B). Ten element leksykalny o pochodzeniu apelatywnym, dość powszechny w użyciu, oznaczał 'pas graniczny, pasmo ziemi obrośniętej trawą na granicy między polami, łanami’33.

${ }^{30}$ Por. nazwy patronalne w dalszej części analizy.

31 Wpływy francuskie w Solothurn wiążą się z tym, że było to tak zwane miasto ambasadorów (Ambassadorenstadt). Poza tym kanton Solothurn graniczy ze strefą francuskojęzyczną na zachodzie w kierunku Biel (Bienne), Neuchâtel. Zob. „Wegen des früheren Sitzes der französischen Botschaft (16.-18. Jh.) — http://de.wikipedia.org/wiki/Solothurn (dostęp: 30.07.2014).

32 Zob. gmina Rain, http://www.rain.ch/de (dostęp: 30.07.2014).

33 Por. „Ein Rain ist ein meist grasbewachsener Grenzstreifen zwischen zwei Äckern oder Fluren.“ — http://de.wikipedia.org/wiki/Feldrain, też http://de.wikipedia.org/wiki/Acker (dostęp: 29.07.2014). 


\section{Leksykalno-semantyczne typy plateonimów}

W badanym materiale spotykamy tradycyjne typy nazewnicze, które z powodzeniem funkcjonują w polskim i niemieckojęzycznym systemie plateonimicznym. Są to zarówno nazwy utworzone od nazw własnych w procesie tak zwanej transonimizacji, jak i nazwy powstałe na bazie apelatywów w procesie onimizacji3 ${ }^{34}$. Oczywiście ich podstawy derywacyjne i każdy z aktów nazewniczych uwarunkowało wiele czynników, z których najważniejsze były: a) położenie, b) historyczny i architektoniczny rozwój danej miejscowości, c) jej społeczno-ekonomiczna charakterystyka (struktura zawodowa, industrializacja, typy własności), d) wpływy kulturalne (interferencje, migracje), e) swoiste wydarzenia w jej dziejach, f) inne aspekty nominacyjne, na przykład przyrodnicze czy metaforyczne. Nazwy te tworzą naturalną siatkę chronologicznie ustrukturyzowanych plateonimów o różnym czasie powstania, odzwierciedlających ich specyficzną stratyfikację, która składa się z jednostek motywowanych o dawniejszej genezie i tych znacznie późniejszych, o charakterze pamiątkowym. Co również ważne, onimy te występują zarówno w strukturze aglomeracji miejskich, jak i w środowisku wiejskim.

\subsection{Plateonimia wsi Bettlach}

Plateonimy w Bettlach mają ścisły związek z miejscowością. W ich zasobie przeważają nazwy utworzone od nazw własnych. Położenie wsi wyznaczają nazwy kierunkowe, na przykład Bielstrasse (miasto Biel), Grenchenstrasse (miasto Grenchen, z którym wieś graniczy), Lebernstrasse (nazwa okręgu Lebern w kantonie Solothurn, w którym leży też gmina Bettlach), Solothurnstrasse (miasto Solothurn) i nazwy górskie, na przykład Alpenweg (Alpen - 'Alpy', tu z wysokości ponad 479 m n.p.m. rozciąga się ich piękna panorama), Bergstrasse (der Berg 'góra'), Chräienbergstrasse (Chräienberg, nazwa w północno-wschodniej części gminy), Hasenmattstrasse (Hasenmatt, nazwa szczytu w paśmie Jury, na wschód od Wandfluh), Jurastrasse (pasmo górskie Jura, u podnóża jego południowego łańcucha powstała wieś).

O rozwoju Bettlach i całej gminy świadczą nazwy jej poszczególnych części, w tym anojkonimy, zwane w typologii szwajcarskiej Flurnamen. Są wśród nich toponimy bardzo dawno zaświadczone i znacznie nowsze, te z ubiegłego stulecia, na przykład Allmendstrasse (Allmend, nazwa północno-wschodniej części gminy; die Allmend(e) - 'wspólna własność' ${ }^{35}$ ), Aristonstrasse (nazwa kwartału z 1912 roku, od choronimu Ariston, to jest nazwy firmy produkującej zegar-

34 Zob. klasyfikacja nazewnictwa miejskiego K. Handke [Handke 1992].

35 Zob. ,Die Allmende, in der Schweiz Allmend, Allmeind oder Allmein, ist eine Rechtsform gemeinschaftlichen Eigentums." Ta forma wspólnej własności była rozpowszechniona w obszarze alpejskim — http://de.wikipedia.org/wiki/Allmende (dostęp: 2.08.2014). 
ki z 1897 roku $^{36}$ ), Bangertli (stara nazwa odnotowana na mapie z 1882 roku $^{37}$ ), Birrholzweg (nazwa drogi na stary cmentarz „Birrholz”38, obecnie znajduje się tu nowy), Bischmattstrasse (nazwa w południowo-zachodniej części gminy ${ }^{39}$ ), Breitenacherweg (Breitenacher, anojkonim), Bruechweg (Bruech, nazwa północno-wschodniej części gminy ${ }^{40}$ ), Büelenweg (Büelen, nazwa północno-wschodniej części gminy), Burghofweg (nazwa Burghof w północnej części gminy), Burgweg (Burg, nazwa północnej części gminy), Bündenweg (dawna nazwa małej części gruntu tak zwanej Bünden ${ }^{41}$ ), Chrüzliacherstrasse (Chrüzliacher, anojkonim), Ebauchesstrasse (Der Ebauches Bettlach AG, nazwa firmy i kwartału ${ }^{42}$ ), Erlimoosstrasse (Erlimoos, anojkonim z 1450 roku, nazwa północno-wschodniej części gminy, por. das Moos - 'mech'), Geissackerweg (Geissacker, nazwa pola, por. Acker - 'pole uprawne'), Grossmatt (anojkonim w centralnej części wsi), Gummenhofweg (Gummenhof, anojkonim, nazwa gospodarstwa), Hänselsmatt (anojkonim), Ischlagweg (Ischlag, nazwa w południowej części gminy), Kastelsweg (Kastels, anojkonim z 1450 roku, nazwa we wschodniej części gminy), Lauacherweg (Lauacher, nazwa w północnej części gminy), Muracherstrasse (anojkonim z 1450 roku), Neue Zelgstrasse (Neui Zelg, nazwa w północno-zachodniej części gminy), Ofenacherweg (Ofenacher, anojkonim z 1450 roku), Sirenacherweg (Sirenacher, anojkonim z 1450 roku $^{43}$ ), Sonnenrain (die Sonne — 'słońce', nazwa osiedla w pólnocno-zachodniej części gminy ${ }^{44}$ ), Riedstrasse (Ried, północno-wschodnia część gminy, por. das Ried - 'sitowie, bagnista łąka, łęg'), Rislenweg (Risle - dolina, wąwóz rzeki Aare ${ }^{45}$ ), Studenweg (Studen, nazwa północno-zachodniej części gminy Grenchen, sąsiadującej z Bettlach), Tannlimattweg (Tannlimatt, anojkonim w południowej części gminy), Wysshärdstrasse (Wysshärd, anojkonim), Witiweg (Witi, nazwa południowej części gminy, prowadzi do rzeki Aare), Zelglirain (Zelg, nazwa północno-wschodniej części gminy).

Historia Bettlach i Szwajcarii znajduje odzwierciedlenie w kilku nazwach osobowych patronów ulic, na przykład Bitzartweg (postać historyczna,

36 Zob. [Leimer 1981: 333].

37 Zob. Diebold Schilling [Leimer 1981: 195-200].

38 Zob. [Leimer 1981: 333].

39 Zob. „Bettlach besteht aus den Ortsteilen Bettlach Dorf, Allmend, Ried, Büelen, Witi, Bischmatt, Zelg, Bruech, Tannlimatt, Ischlag, Kastels, Burg, Bettlachberg und Bettlachstock." http://de.wikipedia.org/wiki/Bettlach_SO (dostęp: 29.07.2014).

${ }^{40}$ Por. też z łaciny brac(c)ae 'spodnie' ,als neben dem Hemd wichtigster Bestandteil der Unterkleidung für Männeroku.“ — http://www.imareal.oeaw.ac.at/cgiimareal/kleioc/0010/exec/kleidlex/ cat2use/\%22kleidlex\%22/acc2use/\%22start\%22/term2use/\%22Bruech\%22 (dostęp: 09.08.2014).

41 „Mit Bünden, Büntfeld bezeichnete man ein kleines Grundstück, das durch Einzäunung von der Allmend abgegrentzt waroku." [Leimer 1981: 24].

42 Zob. [Leimer 1981: 333].

43 Zob. [Leimer 1981: 90].

44 Zob. [Leimer 1981: 334].

${ }^{45}$ Zob. http://www.billerantik.de/products/Holzstiche/Landschaften/Die-neue-Wegeanlagein-der-Aareschlucht-Risle-Schweiz-Klamm-Holzstich-E-15837.html (dostęp: 10.08.2014). 
„Schulmeister”46 z Grenchen, Bettlach w latach 1569-1579), Anna Brotschi-Weg (Brotschi, przedstawicielka jednej z najstarszych rodzin, donatorka kościoła ${ }^{47}$ ), Diebold-Schilling-Strasse (piętnastowieczny kronikarz ${ }^{48}$ ), Ed.-Kummer-Strasse (przedsiębiorca, założyciel firm zegarkowych Ariston, Ebauches, Atlantik w B. ${ }^{49}$ ), Hofergässli (Peter Hofer, właściciel tawerny Bettlachberg ${ }^{50}$ ), Salzerweg (Salzers, jedna z najstarszych rodzin we wsi, nosząca tak zwane Dorfname ${ }^{51}$ ), Walter-Lüthi-Weg (ewangelicki ksiądz, proboszcz Münster w Berno, kaznodzieja, jego rodzina mieszka w B ${ }^{52}$ ). Ważne dla wsi budowle, jak kościoły, restauracje odnajdujemy w nazwach utworzonych od patrociniów, na przykład Markusstrasse (kościół ewangelicko-reformowany), St. Klemenz-Stroku. (kościół katolicki), St. Ursen-Weg (nazwa najstarszej restauracji, tawerny St. Urs z roku $1542^{53}$ ). Wielowiekowa przeszłość tych ziem, ich osadnictwa została utrwalona w nazwach pochodzących od etnonimów, na przykład Alamannenweg (die Alamannen - 'plemię zachodniogermańskie'), Burgunderweg (der Burgunder - 'Burgundczyk'), Frankenweg (der Frank - 'Frank'), Keltenweg (der Kelte — 'Celt'), Römerweg (der Römer - 'Rzymianin'), i szczególnych określeń o charakterze przezwisk, na przykład Guglerweg (Gugler - nazwa najeźdźców z 1375 roku o charakterystycznych spiczastych nakryciach głowy ${ }^{54}$ ).

Wśród plateonimów odapelatywnych na uwagę zasługują dwie zasadnicze grupy. Po pierwsze, rozwój architektoniczny wsi, miejsca ważne z punktu widzenia organizacji życia (kościoły, szkoły, obiekty rekreacji, dworzec), orientacji komunikacyjnej (kierunkowe, topograficzne), dawne zawody jej mieszkańców i obecny status gospodarczy, panujące stosunki własnościowe ilustrują nazwy, na przykład Bachstrasse (prowadzi wzdłuż potoku Giglerbach, por. der Bach — 'strumień, strumyk'), Bahnhofstrasse (der Bahnhof - 'dworzec kolejowy, stacja'), Bahnweg (prowadzi wzdłuż torów, die Bahn — 'kolej, tor, droga'), Baumgartenweg (Baumgarten — 'arboretum'), Breitenstrasse (breit — 'szeroki'), Chappelistrasse (die Kapelle — 'kaplica'), Chürziweg (Kürziweg - 'krótka droga'), Dorfstrasse (das Dorf — 'wieś', centralna ulica), Flurstrasse (der Flur — 'sien, lan, niwa'), Freiheitsstrasse (die Freiheit — 'wolność, swoboda'), Friedhofstrasse (der Friedhof - 'cmentarz'), Gartenweg (der Garten 'ogród'), Grubenweg (die Grube — 'dół, kopalnia'), Güterstrasse (Güter — 'dobra,

${ }^{46}$ Zob. http://de.wikipedia.org/wiki/Schulmeister (dostęp: 10.08.2014).

${ }^{47}$ Zob. Dorfnamen ('nazwania wiejskie') [Leimer 1981: 100].

48 Zob.[Leimer 1981:196],teżhttp://de.wikipedia.org/wiki/Diebold_Schilling_der_\%C3\%84ltere (dostęp: 14.08.2014).

49 Zob. wykaz firm, http://www.mikrolisk.de/show.php?site=280\#sucheMarker (dostęp: 2.08.2014).

${ }^{50}$ Zob. [Leimer 1981: 279].

${ }^{51}$ Zob. [Leimer 1981: 100].

52 Zob. http://de.wikipedia.org/wiki/Walter_L\%C3\%BCthi (dostęp: 14.08.2014). Też [Leimer 1981: 218].

53 Zob. [Leimer 1981: 104, 332].

54 Zob. Die Gugler in unserer Gegend [Leimer 1981: 48). Por. Die Gugel, http://de.wikipedia. org/wiki/Gugel_\%28Kleidung\%29 (dostęp: 2.08.2014). 
towary', prowadzi przy linii kolejowej), Hofstrasse (der Hof - 'dwór, dziedziniec, podwórze, zajazd, zagroda, folwark'), Hohle-Gasse (hohl - 'pusty, wklęsły, wydrążony, spróchniały, zapadły', por. die Höhle — ' jaskinia, pieczara, jama'), Höhenweg (die Höhe - 'wysokość, wzgórze, wzniesienie, góra', położona wysoko), Hübeli (nazwa zaokrąglonego wzgórza ${ }^{55}$ ), Industriestrasse (die Industrie - 'przemysł'), Kirchgasse (uliczka biegnąca do kościoła katolickiego St. Klemenz, die Kirche - 'kościół'), Mattenweg (Matt(e) — „eine Wiese im Alemannischen“, to jest 'łąka' w języku alemańskim ${ }^{56}$ ), Moränenweg (Moränen - 'moreny polodowcowe'), Nagelschmiedweg (der Nagelschmied - 'kowal produkujący gwoździe'57), Rainweg (der Rain — 'granica, miedza'), Reiherweg (die Reihe - 'szereg, rząd, kolej'), Sägeraiweg (die Sägerai — 'tartak'58), Schmittengasse (der Schmied, Schmitt — 'kowal'), Selbststelenweg (die Stele — 'stela, głaz nagrobny, też graniczny', selbst — 'sam'), Sportstrasse (das Sport, obok boiska sportowego w południowej części gminy), Untere Einschlagstrasse (południowa część gminy, też szkoła „Einschlag ${ }^{\text {“59 }}$, por. unter — 'pod; dolny', der Einschlag — 'skręt'), Unterführungsstrasse (die Unterführung — 'tunel podziemny, podziemne przejście dla pieszych').

Drugą grupą są nazwy związane z florą i fauną tego regionu. Środowisko przyrodnicze, szczególnie bogate w lasy, łąki, pola, ogrody, mamy poświadczone w plateonimach utworzonych od wielu gatunków roślin, głównie drzew, na przykład Ahornweg (der Ahorn - 'klon'), Birkenweg (die Birke 'brzoza'), Blumenweg (Blumen - 'kwiaty', die Blume - 'kwiat'), Buchenweg (die Buche — 'buk, buczyna'), Distelweg (die Distel - 'oset'), Eschenweg (die Esche - 'jesion'), Föhrenweg (die Föhre — 'sosna'). W nazwach odnajdujemy też różne gatunki ptactwa występującego licznie w okolicy, na przykład Amselweg (die Amsel - 'kos'), Drosselweg (die Drossel - 'drozd'), Finkenweg (der Fink - 'zięba'), Lerchenweg (die Lerche - 'skowronek'), Meisenweg (die Meise — 'sikorka').

\subsection{Plateonimia Solothurn}

Podobnie jak w Bettlach najliczniej reprezentowane są w Solothurn nazwy ulic utworzone od nazw własnych. Spotykamy tu zatem plateonimy zawierające nazwy dzielnic, kwartałów (o genezie wcześniejszej, nawiązującej do tak zwanych Flurnamen), ale też motywowane Gewässernamen (czyli nazwami wodnymi, głównie potoków, źródeł) i toponimami sąsiednich gmin, osad, wsi i miast. Należą do nich na przykład Allmendstrasse (część miasta, die Allmende - 'teren będący wspól-

55 Zob. nazwa w pobliskiej miejscowości Lengnau, http://www.prospektion.ch/downloads/ burgstellelangnau.pdf (dostęp: 10.08.2014).

56 Zob. Matte (v. mittelhochdt. Mahd „Mähgang“), http://de.wikipedia.org/wiki/Matte (dostęp: 10.08.2014).

${ }^{57}$ Zob. Nagelschmied oder Nagler, http://de.wikipedia.org/wiki/Nagelschmied (dostęp: 2.08.2014).

${ }^{58}$ Zob. Sägewerk, http://de.wikipedia.org/wiki/S\%C3\%A4gewerk (dostęp: 10.08.2014).

59 Zob. szkoła powstała w latach 1972-1974, [Leimer 1981: 335]. 
ną własnością gminy'), Alte Bernstrasse (Bern, stolica Szwajcarii), Baselstrasse (Basel, miasto w północnej części Szwajcarii), Bechburgstrasse (Bechburg ${ }^{60}$ ), Biberiststrasse (gmina Biberist), Bielstrasse (Biel/Bienne, miasto w kantonie Berno), Brüggmoosstrasse (osada Brüggmoos w gminie Rüttenen ${ }^{61}$ ), Brühlstrasse (dzielnica Brühl), Brunnmattstrasse (Brunnmatt, anojkonim), Bucheggweg (anojkonim), Bürenstrasse (gmina Büren), Bürenweg (ts.), Burrisgraben (część Solothurn z historycznymi budowlami ${ }^{62}$ ), Dilitschstrasse (dzielnica Dilitsch), Dornacherstrasse (gmina Dornach), Dreibeinskreuzstrasse (Dreibeinskreuz, nazwa historyczna od oznaczenia przeprawy przez rzekę ${ }^{63}$ ), Dürrbachstrasse (dzielnica Dürrbach, tu potok Dürrbach), Fegetzallee (dzielnica Fegetz), Fegetzhofweg (Fegetzhof, dzielnica, tam znajduje się zabytkowa budowla z 1840 roku $^{64}$ ), Forststrasse (Forst, część miasta), Glutzenhofstrasse (osada w gminie Rüttenen), Grabackerstrasse (anojkonim Grabacker, część miasta), Grenchenstrasse (Grenchen, miasto), Grüneggweg (anojkonim Grünegg), Guggershofstrasse (Guggershof, dawna posiadłość ziemska należąca do parafii św. Mikołaja ${ }^{65}$ ), Gurzelngasse (gmina Gurzeln), Haldenweg (gmina Halden), Hofmattstrasse (Hofmatt, część miasta), Hubelmattstrasse (dzielnica Hubelmatte), Hübeliweg (Hübeli, część miasta, por. der Hügel — 'wzgórze'), Kreuzackerbrücke (nazwa mostu; Kreuzacker, część miasta), Kreuzackergasse, Kreuzackerquai, Kreuzackerstrasse, Loretostrasse (dzielnica Loreto, też kaplica z 1649 roku), Luzernstrasse (Luzern, miasto), Mittlere Greibengasse (dzielnica Greiben), Muttenstrasse (Mutten, część miasta), Nordringstrasse (Nordring 'północna obręcz', część miasta), Obachstrasse (dzielnica Obach, tu: potok Obach), Oberhofstrasse (Oberhof, część miasta), Obere Greibengasse (dzielnica Greiben), Obere Steingrubenstrasse (dzielnica Steingrube), Riedholzplatz (gmina Riedholz), Riedmattstrasse (Riedmatt, część miasta), Sandmattstrasse (Sandmatt, część miasta), Sälirain (pólnocno-zachodnia część miasta), Schöngrünstrasse (dzielnica Schöngrün), Schützenmattstrasse (dzielnica Schützenmatte), Segetzstrasse (dzielnica Segetz), Stalden (gmina w kantonie Wallis ze wsią Stalden, ze względu na dużą liczbę mostów zwana „Brückendorf” — 'wieś mostów'), Untere Greibengasse (dzielnica Greiben), Untere Steingrubenstrasse (dzielnica Steingrube), Wedelswilstrasse (Wedelswil — średniowieczna osada ${ }^{66}$ ), Westringsstrasse (Westring -

${ }^{60}$ Zob. zamek w Oesingen, http://de.wikipedia.org/wiki/Burg_Neu-Bechburg (dostęp: 2.08.2014).

${ }^{61}$ Zob. Rüttenen, http://www.ruettenen.ch/ (dostęp: 3.08.2014).

62 Zob. http://www.solothurnerzeitung.ch/solothurn/das-geschuetzte-solothurner-chuengelimagazin-wird-aufgeruestet-124230529 (dostęp: 10.08.2014).

${ }^{63}$ Zob. O. Noser, Rodel der Seuern an den Bau zu Dreibeinskreuz, „Jahrbuch für solothurnische Geschichte“ 41, 1968, http://dx.doi.org/10.5169/seals-324389 (dostęp: 16.08.2014).

${ }^{64}$ Zob. wykaz dóbr kultury, http://de.wikipedia.org/wiki/Liste_der_Kulturg\%C3\%BCter_ in Solothurn (dostęp: 9.08.2014).

65 Zob. [Strohmeier 1836: 241].

${ }^{66}$ Zob. Historisches Lexicon der Schweiz, http://www.hls-dhs-dss.ch/textes/d/D7715.php (dostęp: 2.08.2014). 
'zachodnia obręcz', część miasta po prawej stronie Aare), Zelgliweg (Zelgli, część miasta), Ziegelmattstrasse (Ziegelmatte, część miasta), Zuchwilerstrasse (gmina Zuchwil).

Na drugim miejscu lokują się nazwy patronalne, odosobowe, co wyraźnie odróżnia plateonimię miejską od wiejskiej (por. analizowana wcześniej plateonimię Bettlach). W tej grupie onimów pamiątkowych znajdują się postaci związane $\mathrm{z}$ miastem, zasłużone dla jego rozwoju (w tym ważną podgrupę stanowią znane w Solothurn rodziny patrycjuszy). Wśród patronów mamy wielu kompozytorów, malarzy, uczonych, profesorów szkół, polityków, pisarzy i właścicieli rodzimych firm. Ciekawą kolekcję tworzą nazwania historyczne, na przykład świętych, królowych i książąt, rycerzy i żołnierzy, przedstawicieli rady miasta, dawnych sołtysów, architektów. Wymieńmy w kolejności alfabetycznej: Amanz Gressly-Strasse (geolog i paleontolog ${ }^{67}$ ), Areggerstrasse (Hermenegild von Aregger, przewodnicząca rady miasta, 1829 rok $^{68}$ ), Berthastrasse (Bertha, burgundzka królowa, założycielka klasztoru St. Ursen, 932 rok $^{69}$ ), Bourbakistrasse (Charles-Denis-Sauter Bourbaki, francuski genera ${ }^{70}$ ), Casimir Meister-Strasse (kompozytor, umarł w S. ${ }^{71}$ ), Cuno-Amiet-Strasse (malarz, grafik, urodzony w S. ${ }^{72}$ ), Edmund Wyss-Strasse (kompozytor, profesor szkoły kantonalnej, związany z S.73), Fialastrasse (Friedrich Fiala, 1817-1888, zasłużony historyk ${ }^{74}$ ), Frank Buchser-Strasse (malarz, podróżnik urodzony w kantonie $\mathrm{S}^{75}$ ), Franz Lang-Weg (Franz Vincent Lang, przyrodnik, rektor, profesor gimnazjum w S.76), Frölicherweg (Wilhelm Frölich, żołnierz, najemnik, bohater zwany „Cesarzem Solury” 77 XV-XVI wiek), Gernsweg (postać historyczna, sołtys ${ }^{78}$ ), Gibelinstrasse (Hans Gibelin, Włoch, budowniczy Baseltor ${ }^{79}$ ), Glutz Blotzheim-Strasse (Robert Glutz von Blotzheim, historyk, pisarz, bibliotekarz związany z miastem ${ }^{80}$ ), Grimmengasse (P. Edmund

${ }^{67}$ Zob. http://de.wikipedia.org/wiki/Amanz_Gressly (dostęp: 4.08.2014).

${ }^{68}$ Zob. http://www.so.ch/parlament/ratsbetrieb/in-kuerze/praesidenten-und-praesidentinnen. html (dostęp: 2.08.2014).

${ }^{69}$ Zob. http://de.wikipedia.org/wiki/Solothurn (dostęp: 12.08.2014).

${ }^{70}$ Zob. http://en.wikipedia.org/wiki/Charles-Denis_Bourbaki (dostęp: 4.08.2014), też BurbakisPanorama in Luzern.

${ }^{71}$ Zob. http://de.wikipedia.org/wiki/Casimir_Meister (dostęp: 4.08.2014).

72 Zob. http://de.wikipedia.org/wiki/Cuno_Amiet (dostęp: 4.08.2014).

73 Zob. http://richardflury.ch/inhalt/pages/weitere-komponisten.php (dostęp: 4.08.2014).

74 Zob. http://www.zbsolothurn.ch/de/zbs/sammlungen/Bestandsfragmente.pdf (dostęp: 16.08.2014).

75 Zob. http://de.wikipedia.org/wiki/Frank_Buchser (dostęp: 4.08.2014).

${ }^{76}$ Zob. http://de.wikipedia.org/wiki/Otto_Möllinger (dostęp: 4.08.2014).

77 Zob. http://www.wirthen.ch/index.php?n=,6 (dostęp: 12.08.2014).

${ }^{78}$ Zob. http://de.wikipedia.org/wiki/Solothurner_Schultheisse_im_Mittelalter (dostęp: 4.08. 2014).

79 Zob. http://www.uov-solothurn.ch/index.php/baseltor (dostęp: 12.08.2014).

${ }^{80}$ Zob. http://de.wikipedia.org/wiki/Robert_Glutz_von_Blotzheim (dostęp: 4.08.2014). 
„Ursus” Grimm von Solothurn, duchowny z XVII wieku ${ }^{81}$ ), Haffnerstrasse (Haffner Franz, postać historyczna, pisarz miejski z XVII wieku' ${ }^{82}$ ), Hans Huber-Strasse (Johann Alexander Huber, kompozytor, pianista ${ }^{83}$ ), Hans Roth-Strasse (Bauer Hans Roth von Rumisberg, rolnik, który uratował S. przed najazdem Habsburgów ${ }^{84}$ ), Holbeinweg (Hans Holbein Młodszy, malarz, twórca obrazu Solothurner Madonna ${ }^{85}$ ), Josef Reinhart-Weg (malarz ${ }^{86}$ ), Jost Greder-Weg (postać historyczna z XVI wieku ${ }^{87}$ ), Küngoltstrasse (Küngolt, bohaterka noweli Dietegen G. Kellera ${ }^{88}$ ), Leopoldstrasse (Leopold I, zasłużony w oblężeniu miasta z 1318 $\mathrm{roku}^{89}$ ) Midartweg (nauczyciel, por. Bettlach), Munzingerweg (Walther Munzinger, prawnik, profesor, reformator, urodzony w Olten ${ }^{90}$ ), Niklaus Konrad-Strasse (postać historyczna, sołtys, zm. w 1520 roku $^{91}$ ), Pisoniplatz (Gaetano Matteo Pisoni, architekt, projektant St. Ursen-Kathedrale, to jest katedry św. Ursa ${ }^{92}$ ), Reinertweg (prawnik, zasłużony dla rozwoju S. ${ }^{93}$ ), Richoweg (bracia Ulrich Richo i rycerz Jost Richo z XIV wieku ${ }^{94}$ ), Schererstrasse (Theodor Scherer-Boccard, publicysta, polityk ${ }^{95}$ ), Schwallerweg (Johann Anton Schwaller von Solothurn, prof. teologii, XVII-XVIII wiek ${ }^{96}$ ), Seilergasse (Alexander Seiler, filmowiec, reżyser, zasłużony dla Festiwalu Filmowego w S. ${ }^{97}$ ), Stauffacherweg (postać historyczna, jeden z twórców die Schweizerische Eidgenossenschaft, uwieczniony w sadze o Wilhelmie Tellu ${ }^{98}$ ), Stephan Jaeggi-Strasse (kompozytor, dyrygent ${ }^{99}$ ), Surbeckstrasse (Surbeck, znana szlachecka rodzina w S. ${ }^{100}$ ), Tscharandistrasse

${ }^{81}$ Zob. http://www.klosterarchiv.ch/e-archiv personen popup.php?id=1323 (dostęp: 12.08.2014).

82 Zob. http://www.hls-dhs-dss.ch/textes/d/D17545.php (dostep: 16.08.2014).

83 Zob. http://de.wikipedia.org/wiki/Hans_Huber_\%28Komponist\%29 (dostęp: 10.08.2014).

${ }^{84}$ Zob. „1382 unternahm das Haus Habsburg durch den Grafen von Neu-Kiburg einen letzten Versuch, Solothurn zu unterwerfen. Der Bauer Hans Roth von Rumisberg vereitelte jedoch den nächtlichen Anschlag auf die Stadt.“ — http://www.stadt-solothurn.ch/de/portrait/geschichte/ welcome.php?action=showinfo\&info_id=3733 (dostęp: 4.08.2014).

${ }^{85}$ Zob. http://de.wikipedia.org/wiki/Solothurner_Madonna (dostęp: 4.08.2014).

${ }^{86}$ Zob. http://de.wikipedia.org/wiki/Josef_Reinhard (dostęp: 4.08.2014).

${ }^{87}$ Zob. hasło Greder, Jost (von Wartenfels), http://www.hls-dhs-dss.ch/textes/d/D17573.php (dostęp: 4.08.2014).

${ }^{88}$ Zob. Dietegen, http://de.wikipedia.org/wiki/Dietegen (dostęp: 12.08.2014).

89 Zob. http://de.wikipedia.org/wiki/Solothurn (dostęp: 12.08.2014).

${ }^{90}$ Zob. http://de.wikipedia.org/wiki/Walther_Munzinger (dostęp: 4.08.2014).

91 Zob. http://de.wikipedia.org/wiki/Solothurner_Schultheisse_im_Mittelalter (dostęp: 4.08.2014).

92 Zob. http://de.wikipedia.org/wiki/Gaetano_Matteo_Pisoni (dostęp: 4.08.2014).

${ }_{93}$ Zob. hasło Reinert, Johann Baptist, http://www.hls-dhs-dss.ch/textes/d/D3104.php (dostęp: 4.08.2014).

94 Zob. źródła archiwalne, http://www.query.sta.be.ch/detail.aspx?ID=62441 (dostęp: 4.08.2014).

95 Zob. http://de.wikipedia.org/wiki/Theodor_Scherer-Boccard (dostęp: 10.04.2014).

96 Zob. http://www.klosterarchiv.ch/e-archiv_personen_popup.php?id=1366 (dostęp: 12.08.2014).

97 Zob. http://www.swissfilms.ch/en/film_search/filmdetails/-/id person/332 (dostęp: 12.08.2014).

98 Zob. http://de.wikipedia.org/wiki/Werner_Stauffacher (dostęp: 4.08.2014).

${ }^{99}$ Zob. http://de.wikipedia.org/wiki/Stephan_Jaeggi (dostęp: 4.08.2014).

100 Zob. http://www.chgh.net/heraldik/s/su/surbecka.htm (dostęp: 12.08.2014). 
(XVI-XVIII wiek, znana rodzina w S. ${ }^{101}$ ), Tugginerweg (Wilhelm Tugginer, XVI wiek, oficer gwardii ${ }^{102}$ ), Verenaweg (święta Verena, według legendy wędrowała wzdłuż rzeki Aare, zmarła w Zurzach ${ }^{103}$ ), Von Sury-Weg (Ernst von Sury, neurolog, lekarz medycyny sądowej, urodzony w S. ${ }^{104}$ ), Walter Hammer-Strasse (założyciel i szef firmy Autophon, 1922 rok $^{105}$ ), Weberngasse (Webern, okręg w kantonie S.), Wengibrücke (Niklaus von Wengi Młodszy, polityk, katolicki sołtys XVI wieku, reformator ${ }^{106}$, rodzina Wengi zasłużona dla S.), Wengisteinstrasse (ts.), Wengistrasse (ts.), Vom Staal-Weg (Vom Staal, zasłużona rodzina XV-XVIII wieku' ${ }^{107}$ ), Von Roll-Weg (Die Von Roll Holding AG, koncern przemysłowy, 1803 rok $^{108}$ ), Von Wigier-Weg (Josef Wilhelm Viktor Vigier, polityk ${ }^{109}$ ), Zeltnerweg (Zeltener Xaver, postać historyczna, senator z XVIII wieku ${ }^{110}$ ), Zurmattenstrasse (Zurmatten Urs, postać historyczna, żołnierz z XVI wieku ${ }^{111}$ ).

Liczne obiekty sakralne, kościoły, kaplice i ich patroni były inspiracją dla nazw utworzonych od patrociniów, na przykład St. Josefsgasse (klasztor), St. Urbangasse (kaplica pw. św. Urbana ${ }^{112}$ ), także zakony dały początek nazwom Franzikanerplatz (kościół, klasztor z 1660 roku), Kapuzinerstrasse (klasztor i kościół z 1588 roku) ${ }^{113}$. Osobliwą nazwą jest Barfüssergasse (Barfuss — 'gołymi stopami') — metaforycznie nawiązuje do zakonu franciszkanów, który przybył do miasta we wczesnym średniowieczu, już w 1280 roku $^{114}$. Zwyczaje związane z karnawałem i świętowaniem przed Bożym Narodzeniem przechowują nazwy, na przykład Hilariweg (Heiliger Hilarius, czyli święty Hilary, w jego dniu, 13 stycznia, rozpoczyna się karnawał tak zwany Fasnacht ${ }^{115}$ ), St. Margarithenstrasse (bractwo, nazwa upamiętniająca między innymi bitwę pod Dornach z 1499 roku $^{116}$ ), St. Niklausstrasse (dzień patrona 6 grudnia, gdy każdy zostaje obdarowany).

${ }^{101}$ Zob. hasło Tscharandi, http://www.hls-dhs-dss.ch/textes/d/D22864.php (dostęp: 4.08.2014).

102 Zob. [Fidele 1751: 522], też http://www.wirthen.ch/index.php?n=,6 (dostęp: 4.08.2014).

103 Zob. http://de.wikipedia.org/wiki/Heilige_Verena (dostęp: 4.08.2014).

104 Zob. http://de.wikipedia.org/wiki/Ernst_von_Sury (dostęp: 4.08.2014).

105 Zob. http://de.wikipedia.org/wiki/Autophon (dostęp: 4.08.2014).

106 Zob. http://de.wikipedia.org/wiki/Niklaus_von_Wengi (dostęp: 12.08.2014).

107 Zob. http://de.wikipedia.org/wiki/Vom_Staal (dostęp: 12.08.2014).

108 Zob. http://de.wikipedia.org/wiki/Von_Roll (dostęp: 12.08.2014).

109 Zob. http://de.wikipedia.org/wiki/Wilhelm_Vigier (dostęp: 12.08.2014).

110 Zob. http://www.hls-dhs-dss.ch/textes/d/D13454.php (dostęp: 12.08.2014).

111 Zob. http://www.hls-dhs-dss.ch/textes/d/D17599.php (dostęp: 12.08.2014).

112 Zob. http://de.wikipedia.org/wiki/Liste_der_Kulturgüter_in_Solothurn (dostęp: 12.08.2014).

113 Zob. Zakon i klasztor Kapucynów, http://de.wikipedia.org/wiki/Kapuzinerkloster_Solothurn (dostęp: 2.08.2014).

114 Zob. [Sigrist 1966: 167].

115 Zob. http://www.lebendige-traditionen.ch/tr-ditionen/00167/index.html?lang=de (dostęp: 10.08.2014).

116 Zob. [Siegrist, Loertscher 1966: 126]. 
Przeszłość miasta, kontakty z różnymi nacjami, osadnikami, najeźdźcami utrwalają nazwy powstałe od etnonimów, na przykład Burgunderstrasse, Judengasse, Keltenstrasse, Römerstrasse.

Geograficzne walory Solothurn, położonego nad najdłuższą rzeką Szwajcarii, podkreślają nazwy wodne, tu znajdują się liczne potoki, a w samym mieście wiele źródeł, historycznych fontann, na przykład Aareweg (die Aare, rzeka), Brühlgrabenstrasse (potok Brühlgraben ${ }^{117}$ ), Schlangenbrunnenweg, Schweikersbrunnenweg, Wassergasse (das Wasser - 'woda', czyli Wodna). Nad miastem góruje pasmo południowej Jury z oddalonym około $5 \mathrm{~km}$ szczytem Weissenstein zwanym „Solothurner Hausberg” ('góra domowa Solury') i stąd mamy nazwy na przykład Bergstrasse (der Berg — 'góra'), Grafenfelsweg (der Fels — 'skała', tu 'skała grafów'), Güggelweg (Güggel — szczyt Jury 1145 m n.p.m. ), Höhenweg (Höhen - 'wyżyny', die Höhe - 'górka, wysokość'), Jurastrasse, Rötibrücke (Röti - najwyższy punkt widokowy Weissenstein 1395,2 m n.p.m. ${ }^{118}$ ), Rötiquai (ts.), Rötistrasse (ts.), Weissensteinstrasse.

Ważnym typem plateonimów licznie reprezentowanym w zebranym materiale są nazwy powstałe od nazw historycznych budowli w mieście, dokumentujących jego rozwój architektoniczny. Solothurn nazywane jest „,najpiękniejszym miastem barokowym w Szwajcarii”, ale jego korzenie sięgają średniowiecza. Dlatego $\mathrm{z}$ wielką pieczołowitością zostały utrwalone nazwy dawnych baszt, fortyfikacji, wałów i murów obronnych. Mamy też plateonimy utworzone od obiektów późniejszych z XVIII i XIX wieku, które świadczyły o dynamicznym rozwoju miasta jako ważnego ośrodka administracyjnego, komunikacyjnego. Są tu nazwy z bazami derywacyjnymi zarówno od nazw własnych, jak i od apelatywów. Wymieńmy je w porządku alfabetycznym: Amthausplatz (Amthaus II przy ul. Westbahnhofstrasse 16, siedziba urzędu), Bastionweg (die Bastion - 'fortyfikacja'), Berntorstrasse (Berntor - zabytkowa brama w kierunku Berna), Besenvalstrasse (Palais Besenval - pałacyk rodziny Besenval, o funkcji hotelu, restauracji, siedziba biskupów ${ }^{119}$ ), Blumensteinweg (siedziba letnia patrycjuszy francuskich zwana „Schloss Blumenstein"120), Dammstrasse (der Damm - 'zapora, tama, grobla, wał ochronny'), Flurweg (die Flur — 'łan, parcela, niwa'), Friedhofgasse (der Friedhof 'cmentarz'), Friedhofplatz (ts.), Glacisstrasse (das Glacis — 'lekko opadająca pochyłość zewnętrznych wałów fortecznych'), Hauptbahnhofplatz (der Hauptbahnhof - 'dworzec główny', zabytkowa budowla z XIX wieku), Hauptbahnhofstrasse (ts.), Herrenweg (Herren - 'panowie'), Käppelihofstrasse (Käppelihof), Kirchweg (die Kirche — 'kościół'), Klosterplatz (das Kloster — 'klasztor'), Königshofweg (Kö-

117 Zob. „Zu den kleineren Bächen zählen der Brunngraben, der Brühlgraben, der Obach, der Dürrbach sowie der St. Katharinenbach (von Westen nach Osten).“ — http://de.wikipedia.org/ wiki/Solothurn (dostęp: 3.08.2014).

118 Zob. http://de.wikipedia.org/wiki/Röti (dostęp: 12.08.2014).

119 Zob. http://www.palais-besenval.ch/home.html (dostęp: 2.08.2014).

120 Zob. [Siegrist, Loertscher 1966: 207]. 
nigshof, budowla historyczna z połowy XVI wieku' ${ }^{121}$ ), Kreuzenstrasse (das Kreuz - 'krzyż'), Kreuzgasse (das Kreuz - 'krzyż'), Kronengasse (hotel i restauracja „Die Krone”), Kronenplatz (ts.), Krummturmstrasse (Der Krummturm — 'krzywa wieża' - średniowieczna wieża obronna na brzegu Aare ${ }^{122}$ ), Lagerhausstrasse (das Lagerhaus - 'magazyn, skład, spichlerz'), Lagerweg (das Lager - 'magazyn, skład'), Landhausquai (Landhaus, budowla z 1722 roku), Löwengasse (historyczna uliczka przy Simsonbrunnen z lwami na Friedhofplatz ${ }^{123}$ ), Marktplatz (der Markt — 'rynek, targ' w znaczeniu ,plac targowy”), Mühleweg (die Mühle — 'wiatrak'), Nictumgasse (por. Narrenzunft Nictum — nazwa bractwa w okresie karnawału ${ }^{124}$ ), Patriotenweg (der Patriot - 'patriota'), Postplatz (die Post - 'poczta'), Poststrasse (ts.), Prisongasse (das Prison - więzienie z 1753 roku $^{125}$ ), Propsteigasse (die Propstei - 'instancja urzędowa w kościele ewangelickim', potem das Pfarrhaus — 'dom proboszcza' katedry St.-Ursen)), Quellenweg (die Quelle — 'źródło'), Rathausgasse (das Rathaus - 'ratusz'), Rathausplatz (ts.), Ritterquai (der Ritter 'rycerz'), Rossmarktplatz (das Ross - 'koń, rumak', dawna nazwa targu końmi), Schaalgasse (Schaal - 'misa', jedna z najstarszych uliczek z XIV wieku), Schanzenstrasse (die Schanze - 'szaniec, wał ziemny, umocnienie'), Schänzlistrasse (ts., Schänzli - 'mały szaniec, wał'), Schlossweg (das Schloss — 'zamek'), Schulhausstrasse (Schulhaus — budynek szkoły kantonalnej), Steinbruggstrasse (zamek Steinbrugg przy Baseltor), Theatergasse (das Theater — 'teatr'), Türmlihausstrasse (Türmlihaus in der Hofmatt — budynek patrycjuszy z XVII wieku), Untere Sternengasse (restauracja Sternen), Vogelherdstrasse (Vogelherd - w znaczeniu Fangplatz - 'miejsce połowu ptaków'126), Waffenplatzstrasse (Waffen - 'bron'), Waisenhausstrasse (das Waisenhaus - 'sierociniec'), Wallstrasse (Wall — 'wał, mur'), Werkhofstrasse (Werkhof, siedziba administracji miejskiej przy Baseltor ${ }^{127}$ ), Westbahnhofstrasse (der Westbahnhof - 'dworzec zachodni'), Zeughausgasse (das Zeughaus — 'skład broni, arsenał', historyczna budowla w S.), Zeughausplatz (ts.). Wreszcie znajdziemy tu nazwy typowo topograficzne, na przykład Oberer Winkel (der Winkel — 'róg, zakątek'), Unterer Winkel (der Winkel — 'róg, zakątek'), Westtangente (West - 'zachodni', die Tangente — 'prosta styczna'128).

121 Zob. http://www.solothurnerzeitung.ch/solothurn/weitere-regionen/der-koenigshof-stehtjetzt-samt-nebengebaeuden-unter-schutz-126987499 (dostęp: 16.08.2014).

122 Zob. http://de.wikipedia.org/wiki/Krummturm (dostęp: 12.08.2014).

123 Zob. [Siegrist, Loertscher 1966: 165].

124 „Als Narrenzunft bezeichnen sich die örtlichen Fastnachtsvereine der schwäbisch-alemannischen Fastnacht. Meistens sind sie die Zünfte der Rechtsform eines eingetragenen Vereins e.V. organisiert" — https://www.webwiki.de/narrenzunft-nictum.ch (dostęp: 12.08.2014).

125 Zob. [Siegrist, Loertscher 1966: 104].

${ }^{126}$ Zob. http://de.wikipedia.org/wiki/Vogelherd (dostęp: 12.08.2014).

${ }^{127}$ Zob. http://www.stadt-solothurn.ch/de/verwaltung/aemter/welcome.php?amt_id=4669 (dostęp: 12.08.2014).

128 Zob. http://de.wikipedia.org/wiki/Tangente (dostęp: 12.08.2014). 
Działalność dawnych cechów znajduje odzwierciedlenie w nazwach odzawodowych, zajęć jego okolicznych mieszkańców, na przykład Fischergasse (der Fischer - 'rybak'), Gärtnerstrasse (der Gärtner - 'ogrodnik'), Gerberngasse (der Gerber - 'garbarz'), Gewerbestrasse (das Gewerbe - 'rzemiosło'), Goldgasse (das Gold - 'złoto' w nawiązaniu do cechu złotników), Meistergasse (der Meister — 'majster, mistrz'), Pirschweg (die Pirsch — z języka myśliwych 'sposób polowania'), Schmiedengasse (der Schmied — 'kowal'). Obraz rozwoju gospodarczego miasta dopełniają też nazwy powstałe od choronimów, na przykład Felsenauweg (Browar Felsenau w S.), Pfisterstrasse (znana firma budowlana Pfister Maler \& Gipser), Zieglerweg (firma Gewinde Ziegler AG z 1932 roku, das Gewinde 'gwint'129) i innych apelatywów, na przykład Fabrikstrasse (die Fabrik), Industriestrasse (die Industrie - 'przemysł'), Werkstrasse (das Werk — 'dzieło, mechanizm, maszyna'). Nieliczne są nazwy nawiązujące do chrematonimów, na przykład

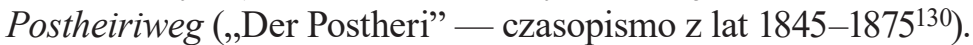

Przyrodnicze walory położenia Solothurn, bogactwo okolicznej fauny podkreślają nazwy odzwierzęce, na przykład Dachsweg (der Dachs - 'borsuk'), Fuchsweg (der Fuchs - 'lis'), Hasenweg (der Hase — 'zając'), Hirschweg (der Hirsch 'jeleń'), Maulbeerweg (das Maul - 'pysk'), Rehweg (das Reh — 'sarna'). Częste są plateonimy z określeniami ptaków, na przykład Adlergasse (der Adler — 'orzeł'), Amselweg (die Amsel - 'kos'), Drosselweg (die Drossel — 'drozd'), Finkenweg (der Fink — 'zięba'), Lerchenweg (die Lerche — 'skowronek'), Meisenweg (die Meise - 'sikorka'), Schwanengasse (der Schwan — 'łabędź'), Storchenplatz (der Storch - 'bocian'). Środowisko wodne związane z rzeką Aare zachwyca różnokolorowymi ważkami, dlatego pojawia się również nazwa Libellenweg (die Libellen - 'rząd ważek liczący wiele gatunków'). Wreszcie w nazewnictwie miejskim Solothurn ważne miejsce zajmują nazwy z określeniami roślinnymi, podobnie jak w Bettlach głównie z gatunkami drzew, na przykład Birkenweg (die Birke - 'brzoza'), Blumenrein (Blumen - 'kwiaty'), Eibenweg (die Eibe - 'cis'), Eichenweg (die Eiche - 'dąb'), Eichweg (die Eiche - 'dąb'), Erlenweg (die Erle - 'olcha'), Eschenweg (die Esche - 'jesion'), Florastrasse (die Flora — 'świat roślin'), Holunderweg (der Holunder - 'czarny bez'), Lindenweg (die Linde - 'lipa'), Nelkenweg (die Nelke - 'goździk'), Pappelwegg (die Pappel — 'topola'), Rosenweg (die Rose - 'róża'), Tulpenweg (die Tulpe - 'tulipan'), Ulmenweg (die Ulme 'wiąz'), Veilchengasse (das Veilchen - 'fiołek'). Określenia przyrodnicze dotyczą mniej ważnych ciągów komunikacyjnych z członem -weg, -gasse i są rozlokowane tematycznie w określonej części miasta.

129 Zob. http://www.gewindeziegleroku.ch/portrait-film.phtml (dostęp: 15.08.2014).

${ }^{130}$ Zob. http://www.hls-dhs-dss.ch/textes/d/D24777.php (dostęp: 12.08.2014). 


\section{Osobliwości nazewnicze}

W badanym materiale spotykamy charakterystyczny dla Szwajcarii przyrostek spieszczająco-zdrabniający - $l i^{131}$, na przykład Schanzenstrasse - Schänzlisstrasse. Obserwujemy też elementy leksykalne zaczerpnięte z języka alemańskiego, na przykład Matt(e) w znaczeniu Bergwiese 'hala, łąka w górach', znajdujące się w wielu Flurnamen i Verkehrsnamen, tu choćby Mattenweg Ziegelmattstrasse. Warto też przywołać notowane na starych planach wsi Bettlach z 1822 roku formy Neu Zelg, Rüttimatt, Burgzelgli, Altrüttiberg, Bruechfeld ${ }^{132}$. Nazwa Zelg (w althochdeutsch apelatyw zêlga) oznaczała formę uprawy pól wprowadzoną przez Alemanów ${ }^{133}$ i dlatego pojawiały się określenia jak na przykład Sommer-, Winter-, Brachzelg. Słowa Reuti, Rütti, Rüttenen związane są z gospodarką leśną, tak zwaną Rodung 134 (wycinką, obróbką drewna itp.) i pozyskiwaniem ziemi na cele rolnicze. Dlatego też badacze podkreślają wagę kulturową tego rodzaju Ortsnamen i w związku z nimi wymienia się często inne skojarzone bazy leksykalne, jak na przykład Brand ('pożar', w związku z wypalaniem lasów lub pozostałości po ich wyrębie) lub Stock (w znaczeniu 'pień, pniak'), które często występują w nazwach złożonych. Kolejną charakterystyczną formą alemańską jest die Hufe, oznaczająca jednostkę miary powierzchni, ziemi należącej do wolnych rolników, którą przekształcono w nazwy Hube, Hueb lub Huber ${ }^{135}$. I wreszcie odnotowana w plateonimach wsi Bettlach nazwa z określeniem Bünden (też tworzona od niej Büntfeld) odnosi się do małego kawałka ziemi oddzielonego od tak zwanej wspólnej ziemi Allmend ${ }^{136}$. Typowe dla szwajcarskich nazw geograficznych tak zwanych Ortsnamen, które były podstawami do tworzenia licznych plateonimów, w szczególności wiejskich, są zakończenia o charakterze topograficznym, na przykład elementy -berg, -bühl, -egg, -halden, też -rain, wskazujące na położenie obiektu na wzniesieniu, na pagórku, wzgórzu. Dodatkowo odnotowuje się sporo nazw zawierających znaczenie pola, łąki (Feld, Wiese), wyrażone członami -acher, -feld, -matt lub -wang. Zwraca uwagę również wielki wpływ języka mówionego na tworzenie i formy toponimów, co zaświadcza o niezwykłym bogactwie kulturowo-językowym kantonów i w związku z tym oryginalne, dialektalne formy onimów godne są udokumentowania źródłowego oraz zachowania ich jako jeden ze śladów przeszłości tych ziem ${ }^{137}$.

\footnotetext{
131 Zob. przyrostek -li, http://de.wikipedia.org/wiki/-li (dostęp: 30.07.2014).

132 Zob. [Leimer 1981: 23].

133 Zob. objaśnienie "die Dreifelderwirtschaft" [Leimer 1981: 24].

134 Zob. http://de.wikipedia.org/wiki/Rodung (dostęp: 10.08.2014).

135 Zob. [Leimer 1981: 24].

136 Zob. [Leimer 1981: 24].

137 Zob. [Saladin 1942-1944: 239].
} 


\section{Podsumowanie}

Przedstawiona analiza odwołuje się do dzisiejszego stanu nazewnictwa, nie rozwiązuje etymologii i historycznego pochodzenia Flurnamen ${ }^{138}$, które dały początek wielu nazwom wtórnym, nie podaje dokładnej stratygrafii nazw ani zapisów źródłowych. Tego typu opracowanie wymaga pogłębionych studiów i opracowania monograficznego. Mimo tych ograniczeń przedstawiony opis in statu nascendi pozwala na ukazanie określonych prawidłowości w tworzeniu zasobów plateonimicznych Solothurn i Bettlach, które niewiele odbiegają od głównych typów obserwowanych w Polsce ${ }^{139}$. Godne podkreślenia jest natomiast pieczołowite pielęgnowanie tożsamości kulturowo-językowej nazw, ich głębokie osadzenie w historii i tradycji szwajcarskiej.

\section{Bibliografia}

\section{Źródła drukowane}

Beat Fidele Antoine Jean Dominique Baron de La Tour-Chatillon Zurlauben, Histoire militaire des Suisses au service de la France, avec les pieces justificatives. Paris, Desaint et Saillant 1751-53. Gelbe Seiten Grenchen, Solothurn und Umgebung 2012. Verlag und Herausgeber: LTV Gelbe Seiten AG, Thurgauerstrasse 40, Postfach 8052 Zürich.

Infoblatt 2012. Einwohnergemeinde Bettlach, City-Offset, Grenchen, 2. Ausgabe 2011/2012.

\section{Strony internetowe}

http://books.google.ch/.

http://de.wikipedia.org/wiki/.

http://www.historischer-verein-bettlach.ch/.

http://ortsnamen.ch/.

http://www.palais-besenval.ch/home.html.

http://pl.pons.com/.

http://www.chgh.net/heraldik/.

http://www.hls-dhs-dss.ch/.

http://www.klosterarchiv.ch/.

http://www.so.ch/.

http://www.solothurnerzeitung.ch/.

http://www.stadt-solothurn.ch/de/.

http://www.swissfilms.ch/.

http://www.query.sta.be.ch.

http://www.wirthen.ch/.

138 Zob. [Hofmann-Wiggenhauser, Reber 2014].

139 W motywacji polskich plateonimów główną rolę odgrywa pragmatyzm i czynniki kulturowe. Zob. [Oronowicz-Kida 2014, też Myszka 2016]. 


\title{
Opracowania
}

Flüerer N. (red.), 1982, Kulturführer Schweiz in Farbe, Ex Libris Verlag, Zürich.

Handke K., 1992, Polskie nazewnictwo miejskie, SOW, Warszawa.

Hofmann-Wiggenhauser B., Reber J., 2014, Vom Amerikanerblätz zum Zirzel, Flurgeschichten aus Olten-Gösgen und Thal-Gäu, Knapp Verlag, Olten.

Leimer E., 1981, Bettlach. Geschichte und Geschichten, Einwohnergemeinde, Gubler AG, Lengnau. Myszka A., 2016, Urbanonimia Rzeszowa. Językowo-kulturowy obraz miasta, Wydawnictwo Uniwersytetu Rzeszowskiego, Rzeszów.

Oronowicz-Kida E., 2014, Oficjalne nazwy wiejskich ulic w województwie podkarpackim. Studium językowo-kulturowe, Wydawnictwo Uniwersytetu Rzeszowskiego, Rzeszów.

Saladin G., 1942-1944, Geordnete Schreibung der Ortsnamen, In: „Schweizerisches Archiv für Volkskunde (Archives suisses des traditions populaires)“, Band (Jahr): 40 (1942-1944), 239255. Wersja zdygitalizowana w PDF, http://dx.doi.org/10.5169/seals-113841.

Sigrist H., Loertscher G., 1966, Solothurn, Edition Generales S.A. Benjamin Laederer, Verlager, Genf.

Strub W., 1949, Heimatbuch Grenchen. Die vergangenen Jahrhunderte bis in die Gegenwart dargestellt, Verlag: Vogt-Schield A.G., Solothurn.

Strohmeier U.P. 1836, Der Kanton Solothurn: Historisch, geographisch, statistisch geschildert: Beschreibung aller in demselben befindlichen Berge, Seen, Flüsse, Heilquellen, Städte, Flecken...; ein Hand- und Hausbuch für Kantonsbürger und Reisende, Bei Huber und Campagnie, St. Galen und Bern. Zob. Wersja zdygitalizowana na http://books.google.ch/.

\section{Cultural and linguistic features of German language toponyms in Switzerland. Contemporary urban toponyms in Solothurn and Bettlach}

\begin{abstract}
Summary
Polish scholars have not yet examined Swiss toponyms. The paper analyzes contemporary names of streets and squares of two municipalities in the canton of Solothurn, which has many historical ties with Poland. The primary focus is on the linguistic and cultural specificities. The paper also illustrates the fact that the main types of analyzed names (derived from city names, derived from names of persons, derived from common words) are widespread in Europe. The paper refers to historical and onomastic research from Switzerland.
\end{abstract}

Keywords: toponyms, cultural identity, urban toponyms, Solothurn and Bettlach 